\title{
THE IMPACT OF THE ACCOUNTING NORMALIZATION AND HARMONIZATION ON THE PRESENTATION OF THE ACCOUNTING- FINANCIAL INFORMATION
}

\author{
Ph.D. Student Mioara Turcas, Academy of Economic Studies Bucharest, $\underline{\text { mioara.turcas@btrl.ro }}$
}

\begin{abstract}
In order to face some irreversible and of general concern accounting processes such as: the ground of the stock exchange capitalization, the development of the stock markets, the globalization of economies and the foundation of multi-national corporations the normalization by harmonization or by international convergence and the applications of IFRS is required.
\end{abstract}

The financialaccounting information represents without doubt one of the main information source of any decisional process. Starting with the reports on the obtained production or stocks and to the elaboration of the annual accounts the reason is the same: to support various categories of users in choosing the optimal solutions.

As a consequence of the globalization of economies, the set up of international corporations, the increase of the stock exchange capitalization, the development of the capital market and the creation of new financial products, the accounting faces today some irreversible processes of great importance. In such conditions, on the background of relevance, credibility and comparability, the production and communication of information are vital for business. To the aforesaid three characteristics one can add the need of formalism, implicitly, a shared accounting language which should be able to ensure communication between all categories of information users.

The elaboration of accounting norms represents a social decision being as the situation may request, a individual product or a simultaneous one with a political action, logical reflection or some empirical results.

The objectives of the normalization of accounting are: elaboration of unitary terminology and general accounting principles; definition of the presented information in the accounting synthesis documents (financial reports); establishing of schemas and information presentation models within the synthesis documents; elaboration of accounts' plans and monographers of the main economic and financial operations; establishing the principles of book keeping. The acceptance of norms by the affected parties (social protagonists) can be forced or voluntary, or both in the same time.

The normalization of the annual financial reports is proper to the Anglo-Saxon countries and is consisted of:

- The contents of fina ncial reports;

- The descriptive elements of the financial reports, recognition and assessment of such elements;

- The contents of various cells;

- The accounting regulations, standards and procedures on the elaboration and presentation of financial reports.

In the terms of normalization, order and format of the presented elements of the financial reports are not imposed.

The normalization with general accounting plan is proper to the Western European countries and the term of accountancy plan belongs to the field of accountancy from France.

The normalized elements are:

- Annual financial reports, including the form and format; 
- The general accounts plan (accounts system, description, symbol, contents, accounting function);

- Organization of accounting documents and operations record, validation and control procedures.

In Romania the normalization of the economic agents' accounting is regulated by:

- The Act of Accounting No.82/1991, later completed and revised by several Governmental Decisions;

- Accounting regulations for economic agents and public institutions;

- Methodologies and accounting stipulations having the status of regulations;

- Methodological instruments having the status of professional guides;

- General framework for drafting and presentation of financial reports issued by the International Accountancy Standards Board (IASB);

* The network of standards and accounting norms is defined by:

The International Financial Report Standards (IFRS), called until 2003 the International Accounting Standards (IAS);

The European Accounting Directives;

The National Accounting Standards as developments according to the Accounting Directives of the EU, the general framework of IASB and in convergence with IFRS;

IFRS/IAS;

* The supplementary National Accounting Standards for the areas that are not covered by

- General Accounts Plan;

- Recommendations and practical guides;

- The Act of Financial Audit

The primary reason that imposed normalization of accounting is the increase of the social role of accounting information as background of the economic decisions taken by users of the accounting information such as: state, suppliers, clients, banks, auditors, financial administration, employees, national statistics.

Due to the great diversity of required information by users or provided by the patrimonial institutions some quality features of the financial reports are strictly delimitated. These focus on understandability, relevance, credibility and comparability of the presented information.

One can characterize the former years as years of search for a way to obtain powerful information. There are still obstacles in obtaining a close to perfection information:

- Conflict situation between the requested qualities of the accounting information;

- Difficulties in selection the relevant information within a given context;

- The "fantastic" rhythm of "news" in the world of financial report with negative effects on comparability of the presented information;

Subjectivity found unfortunately in the assessment of the patrimony, determined by interests of a group of "privileged" users of the accounting information, impossibility of quantifying all aspects that influence an entity (namely, aspects of competition, training of the own staff or impact of the quality of management on the achieved performances) are obstacles on the way to obtaining the truth.

Reports achieved on the bases of costs to the prejudice of true values, retrieved in practice of many companies looks like illustrating the "past" in detriment of forecasting.

Accounting is actually under the pressure of the users of information provided. Whether we like it or not, such pressure represented by various requests coming from users of information determine the search for general accepted solutions, acceptance being not similar to imposing.

The accounting normalization process is necessary in determining a reference framework having as fundamental goals the following three aspects:

1. Public power should obtain a homogenous information referring to enterprises; 
2. Increasing the value of appreciation of the accounting information by external users as concerns time and space connected comparisons;

3. Contribution to a better financial resources allocation at country level.

By normalization one obtains a real "black box" of the whole activity of a entity in the assessed time span, which is the starting point in the analysis of the achieved performances not only with previous results but in comparison with other competitors and a launching platform for future activities.

The normalization process also provides a tool of communication between the entity and various user categories.

At the time being there could be mentioned four normalization approaches defined by L.A.Daley and G.E. Muller:

1. The political approach where the state's interventions are dominant: the French and German cases are the most illustrative;

2. The pragmatic approach where the liberal accountant profession (see the case of Britain) plays a decisive role in drafting and putting into application the regulations;

3. The mixed approach where the regulations elaborated by the professional organizations are validated by public intervention: the case of the USA where the Securities and Exchange Commission plays the role of regulator of the communications on the financial information of the quoted companies which also mandates the Financial Accounting Standards Board (FASB) to issue an assembly of general accounting principles that are admitted.

4. The mixed approach is the result of a long process where regulations are the result of compromises made by the syndicates, the accountant professionals and patronage associations: namely the Tripartide Overleg from the Netherlands; later on, the Committee was replaced by the Foundation for Accounting, which is a private organization that gather 4 organizations of syndicate and patronage plus the representatives of the accountant profession; an important particularity of the Dutch situation is the presence of tight relations between the profession and the academic environment.

The success of the accounting practices represents only the edge of the pyramid based on a solid accounting theory.

At the time being, the attention is focused on the quality of the information and assurance of compatibility between several countries, many countries proposing new regulations and acts.

An acute issue is the harmonization of accounting at regional and/or global level.

At regional and global level coexist several accounting cultures, two of them having a big influence.

1. The accounting culture and the accounting system from Western Europe named also Continental, is promoted by France and Germany;

2. The English-Saxon accounting culture and the accounting system is promoted by England and the USA.

Under the influence of these two blocks of accounting power, the national accounting systems present big divergences, which have generated mostly after the II World War the initiation of the harmonization process, of approaching between the accounting systems of various countries or groups of countries. Such harmonization is requested mainly by the big international investors "who want to safely compare under equivalent criteria the opportunities of placing the capital", goal that can not be achieved if the companies are not ready to observe the same rules of publication of their economic-financial information. The key of success in such harmonization process is represented firstly by the flexibility of such process in choosing general accepted solutions. In this respect, on regional level there have been set up international governmental and non-governmental bodies that focus on active contribution to the harmonization of accounting.

The classification of the implied international and professional bodies into the normalization and harmonization of the international accounting can be presented as follows: 
a. Non-governmental organizations

- United Nations Organization (UNO)

- European Union (EU)

- Organization for Economic Cooperation and Development (OECD)

- International Organization of Securities Commissions (IOSCO)

b. Professional Organizations of Accounting

- International Federation of Accountants (IFAC)

- European Federation of Accounting (EFA)

IFAC is a private body for cooperation and study at global level, the representative of the international accounting bodies. It is interested in the field of audit of the professional practice, ethics, training in the field of accounting and publication of its suggestion in studies and recommendations. The President of IFAC participates with consultative vote to the Council of IASC, council in which other two observers take part (without voting right); one representative of the American Body for Normalization (FASB) and a representative of the European Commission.

The European Federation of Accounting gathers professional associations of accountants within the European Union and plays an important role of studying and consulting - similar to the IFAC but at community level. The Organization for Economic Cooperation and Development (OECD) has created in 1978 a working group for accounting norms connected with the preparation of the accounting harmonization and for the assurance of the comparability between the accounts published in the industrial countries. OECD has no power of regulation and cannot draft accounting norms but the discussions held within the office between the participants can influence the accounting norms that are under preparation.

International Accounting Standards Committee was founded in June 1973 as a consequence of the convention between the accountant bodies from Australia, Canada, France, Germany, Japan, Mexico, the Netherlands, Great Britain and Ireland as well as the United States of America. IASC has represented "the starting point" in the process of normalization and harmonization of the international accounting. Setting up such body was successful relatively soon, fact that illustrated once again the necessity of such approach.

Thus, in 1990, the number of member organizations rose at 100 accountants organizations from 80 countries and at January $1^{\text {st }}, 2000$, the number of members was of 143 belonging to 104 countries.

The International Financial Reports Standards are accounting standards and interpretations issued by IASB, an independent organization set up for issuing accounting standards in order to be applied at global level.

A new start up for the international harmonization and normalization of accounting has happened in March 2001, the moment of setting up of the IASC Foundation, non-profit society, "parent" of the new International Accounting Standards Board (IASB). Started effectively to work at April $1^{\text {st }}$, 2001, IASB has assumed the responsibilities of its predecessor - the International Accounting Standards Committee (IASC) and has focused on "wording and issuing of accounting norms of general purpose that could be used for the elaboration and publication of financial reports and promoting acceptance and application of such norms worldwide".

The norms issued before 2001 preserved the generic title of "international standards of accounting" those issued after 2001 have been called" international norms of financial report".

The debate between the two accounting worlds namely the Anglo-Saxon and the EuropeanContinental is present especially when one talks about exercised influences beyond the national, cultural or any other type of borders. Some authors consider the IASC initiatives only a Britain attempt to somehow counterbalance the Continental influence (especially the German one) on the European directives. Whether we like it or not we should consider the sayings of Christofer Nobes: "IASC seems to be a Trojan Horse that hide inside the enemy "the Anglo-American accounting" behind a well respected international façade. The horse is pushed into the heart of Europe and then 
its contents contribute to the sub-mining of the traditional continental accounting". It is not contested by either parties the fact that IASC become actually IFRS and represents the spread edge in the battle for information that is at the very beginning.

\section{Counterarguments brought to the process of accounting normalization}

The historical aspects represent the first category of counterarguments brought to the process of normalization. The appearance of normalization is considered as "an accidental historical interpretation" resulted from the stock exchange crises between 1929-1933. The adepts of this variant invoke the lack of a structured assembly of accounting principles in the specialty literature until the beginning of the $20^{\text {th }}$ century.

As political argumentation the appellants of normalization have brought up the fact that the main objective of normalization is not the economic efficiency or the concept of equity but the meeting of the requirements of interested groups.

The elaboration of accounting norms is considered more a product of political action than result of the logical and empirical discoveries. Why?-Because the elaboration of norms is a social decision. Norms establish behavior restrictions and those have to be accepted by the affected parties. The acceptance can be forced or voluntary. In a democratic society obtaining acceptance is a complicated process that requires a lot of work in the political filed." (Horngren, cited by K.Naser in "Creative accounting: its nature and use").

The last category of arguments against normalization is represented by the economic reasons. The process of accounting normalization implies a big volume of costs (direct and indirect). The direct costs comprise the required resources consumed by the body in charged with the normalization in order to develop the financial divulgation and to enforce conformity with norms. The indirect costs result from the impact of normalization on the decisions of investing, financing and production. The result shows that the benefits obtained by amelioration of social welfare are not enough to equalize the costs of normalization. Between simplicity and intelligibility, between costs and advantages the market of accounting information needs the process of normalization.

Beyond the interests of the producer of information or of diverse user categories taken into consideration, the process of normalization is called to find a balance point under the diverse challenges of the economic environment. At what extend approaches the accounting information to the social optimum? On one hand, one can find the manager's behavior in the case of hearing "bad news" referring to the company he leads. In an excess of prudence such information are processed or dissimulated before divulgation to external users. On the other hand, one can retrieve the variety of accounting procedures at the disposition of the accounting information provider and the different impact of each option on the decisional process.

Major existing differences between accounting practices in the Anglo-Saxon countries and the European continental ones, e.g. referring to the aspects connected to the assessment of patrimonial elements, the recognition of incomes and debts, the accounting of special contracts or the elaboration of consolidated accounts remain obstacles on the way towards accounting normalization.

Accused by lack of objectivity and directly or indirectly influencing the stock exchange of the company, the accounting information remains however a "magic mirror" of any user. Therefore, the accounting normalization can be defined also as an ally of the construction of the "accounting truth". Bernard Colasse has made the remark that normalization is socially legitimate while it is a "collective approach that focus on the knowledge improvement rather than to explain consequences, difficulties limits and... threats" of such knowledge. Under the given circumstances the elaboration of accounting norms seems to be a debated subject in the forthcoming years. 


\section{Bibliography:}

1. Gh.Valceanu, V.Robu, N.Georgescu (coordonatori)- Analiza economico- financiara, Ed.Economica, Bucuresti,2005

2. A.Isfanescu, V.Robu, A.Hristea, C.Vasilescu- Analiza economico-financiara, Ed.ASE,2002

3. N.Feleaga, I.Ionascu -Tratat de contabilitate financiara, Ed.Economica, 1998

4. N.Feleaga- Sisteme contabile comparate, Ed.Economica, 1999

5. N. Feleaga, I. lonascu - Tratat de contabilitate - vol. I si II. Ed. Economica. 1998.

6. M. Ristea - Metode si politici contabile. Ed. Economica. 2000.

7. N.Feleaga, I.Ionascu -Tratat de contabilitate financiara, Ed.Economica, 1998

8. Stefan Bunea - "Lumini si umbre în prezentarea si interpretarea performantei" Contabilitatea, expertiza si auditul afacerilor, nr.3 martie, 2001

9. B.Colasse- La gestion financière de l'entreprise, PUF, Paris, 1993

10. Laurence Binet- Les etats financiers anglo-saxons, Comparaison avec les etats financiers francais dans le cadre de l'harmonisation internationale, Economica, Paris, 1991

11. Louis Klee, M.Aquillar- La comptabilite des societes dans la CEE. La Villeguerin Editions, 1992 